\title{
URBAN HERITAGE MONITORING, USING IMAGE PROCESSING TECHNIQUES AND DATA COLLECTION WITH TERRESTRIAL LASER SCANNER (TLS), CASE STUDY CUENCA - ECUADOR
}

\author{
V. Heras ${ }^{1, *}$, E. Sinchi ${ }^{2}$, J. Briones ${ }^{2}$, L. Lupercio ${ }^{3}$ \\ ${ }^{1}$ Design, Architecture and Arts Faculty, Universidad del Azuay, Cuenca-Ecuador - vheras@uazuay.edu.ec \\ ${ }^{2}$ Architecture Faculty, Universidad de Cuenca, Cuenca-Ecuador - edison.sinchit@ ucuenca.edu.ec, jcbo22@gmail.com \\ ${ }^{3}$ Agricultural Sciences Faculty, Universidad de Cuenca, Cuenca-Ecuador - lucia.lupercio@ucuenca.edu.ec
}

Commission VI, WG VI/4

KEY WORDS: Urban heritage, digital documentation, Terrestrial Laser Scanner, heritage monitoring.

\begin{abstract}
:
The role of heritage documentation has proven beneficial for the conservation and management of built heritage. Different tools has supported the recording of buildings, city buildings blocks and sites. However, in most of the heritage sites a lack of systematic methodologies for adequate data analysis has revealed the misusing of heritage documentation. Thus, sites enlisted as World Heritage Sites (WHS) by the UNESCO, are dealing with values that remain at the urban scale, while the documentation activities are focused mainly in buildings.

These situation suits to many sites in developing countries, such as the historic city of Cuenca, at the south of Ecuador. The UNESCO included Cuenca as a WHS in 1999 due to important heritage features. Nevertheless, these heritage values remain at the city level, while the documentation tools and used techniques are focused in individual elements making more difficult the control and management decision-making at the city level. In this context, this research contributes to heritage management; by exploring documentation techniques that provide detailed information and that support heritage analysis at different scales from the urban level, city building blocks and heritage building.

Thereby, the digital aerial photogrammetry, orthomosaics and Model Digital Terrain (MDT) were used to allow the acquisition of an aerial representation of the historic landscape of the city. These data combined with other existing heritage registers, enable the identification and analysis of different valuable elements at different scales. The results has demonstrated that combination of different heritage tools improves heritage conservation with less economic resources.
\end{abstract}

\section{INTRODUCTION}

In recent years, there have been significant advances in different digital documentation techniques such as Close Range Photogrammetry, Stereo-photogrammetry, Terrestrial Laser Scanner and Rectified images, among others. These developments are caused due to several factors like the application of computer vision techniques, the increase of the quality of low cost digital cameras, or the significant development of photogrammetric software (Green, 2014). The described progresses led to a fast and widespread use of digital documentation techniques at different levels of approach (buildings, city buildings blocks or the urban level) all related to Cultural Heritage (Bolognesi, 2015). By consequence, a growing number of researches began to explore the correct use of low cost digital documentation techniques in order to obtain sufficiently accurate 3D models of the surveyed objects (Koutsoudis et al, 2014).

Despite the mentioned investigations and improvements, for different world heritage sites mainly located in developing countries have long faced difficulties with the theoretical as well as practical challenges of managing continuity on the scale of historic cities. Identifying individual components of built heritage and selected areas for a variety of levels of conservation through the implementation of inventories, has largely accepted to be the main achievements (Briones, J., et.al, 2017).

In this context, the historic city of Cuenca, located at the south of Ecuador, illustrates the previous described situation. Since 1999, Cuenca is part of the of World Heritage List due to the following criteria: 1) Cuenca retains colonial urban planning features, 2) In the city the fusion of different cultures is evident and 3) The street pattern is an example of inland Spanish colonial town (United Nations Educational, Scientific and Cultural Organization - UNESCO, 1999). Public institutions like the Municipality and the National Heritage Institution (Instituto Nacional de Patrimonio - INPC) are uncharged of heritage conservation in Cuenca (COOTAD, 2010). Consequently, different documentation processes had been implemented aiming to ensure the maintenance and conservation of built heritage in terms of its materials, building techniques, history and cultural significance. So four inventories were applied in the historic city of Cuenca in different periods: 1975 - 1978, 1980 - 1982, 1999 and 2010 (Heras, V., et.al, 2016). Even of the existence of these and other projects related to documentation attempts, the resulting heritage data describes single buildings while, as it was described above, the valuable features of Cuenca remain at the urban scale (See figure 1). Besides, the valuable existing data up today is not updated. It strongly hinders the efficient and

\footnotetext{
* Corresponding author
} 
optimal use of the available heritage information in management issues. Consequently, the urban heritage values are at risk of suffering unnecessary losses.


Figure 1. Map of the inventoried buildings in the historic centre of Cuenca - Ecuador.

(C) vlirCPM project, 2011

\section{METHODS}

As it was mentioned in the introduction, this research started by establishing management strategies, aims and objectives for the study area, in this case it will be presented at the urban level. Then the description of the historical character of the historical area is established. As a third step, the identification and assessment of heritage values and tangible attributes are proposed. Once the valuable elements at the urban scale are determined, a documentation technique is selected in order to gather the data that can contribute to heritage management analysis. Finally, the required analysis are executed (See figure 2). The results can demonstrate and validate the selection of the documentation technique.

As the main objective of this paper is the use of image processing techniques and data collection with digital documentation tools at the urban scale, the heritage management requests and the description of the study area will not be deepened. However, in general terms the main management requirements of the historic city centre of Cuenca are the change control and monitoring of heritage values, valuable features, materials of the inner courtyards, and the land use of the city building blocks. The results are crucial for a city with a small budget and almost 3259 heritage goods spread in

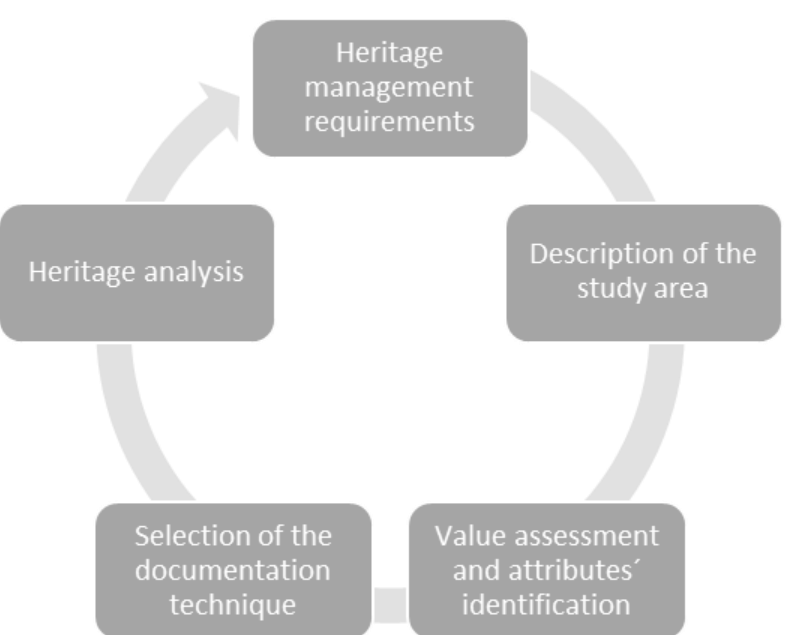

Figure 2. Heritage management process for the historic centre of Cuenca - Ecuador.

224,14 ha. In this case, the data should be gathered at different scales such as the building scale, the city building block and at the urban level. Moreover, this data needs to be reliable and regularly updated.

For the selected study area, it is important to mention that this research focuses on 16 city building blocks of the UNESCO enlisted area. The buildings that conform the selected city building blocks were part of the last heritage inventory; it means that basic data such as the building construction year, façade materials, state of conservation, etc. was already collected. Nevertheless, this research meant to gather data that do not exist and mainly that it can allow future analysis at the city building block level.

\subsection{Value assessment and attributes identification}

An essential part of this research was the value assessment process and the later attributes identification. For the understanding of heritage values, this research aligned to the concept given by Caraballo Ciro (2011), who states that the values cannot be considered homogeneous neither permanent nor socially objective. Therefore, these values are transferred to cultural goods and events that serve as a reference for monitoring and control aspirations. In the city of Cuenca, the urban scale is the case study, thus, the Outstanding Universal Value (OUV) statement and the OUV criteria of the WHS of Cuenca were used as the bases of the research (United Nations Educational, Scientific and Cultural Organization - UNESCO, 2008). Then, the identified values were structured in the NaraGrid, which supported the valuable features determination. The Nara-Grid was determine as an appropriate tool to integrate the identified values and the valuable features (attributes) into a coherent structure (Van Balen, 2008). Once they were established, an example of the type of data needed for control and monitoring purposes is shown in table 1. 


\begin{tabular}{|c|c|c|c|}
\hline $\begin{array}{c}\text { OUV } \\
\text { Criteria }\end{array}$ & $\begin{array}{c}\text { Heritage } \\
\text { value }\end{array}$ & $\begin{array}{l}\text { Valuable } \\
\text { features }\end{array}$ & Data type \\
\hline \multirow{4}{*}{$\begin{array}{l}\text { Cuenca is a } \\
\text { vivid and } \\
\text { tangible } \\
\text { experience } \\
\text { of the urban } \\
\text { planning } \\
\text { principles } \\
\text { and } \\
\text { territorial } \\
\text { strategies, } \\
\text { developed } \\
\text { during the } \\
\text { renaissance } \\
\text { and used for } \\
\text { the creation } \\
\text { of the } \\
\text { colonial } \\
\text { cities in the } \\
\text { American } \\
\text { territory. }\end{array}$} & $\begin{array}{l}\text { Historic } \\
\text { value }\end{array}$ & $\begin{array}{l}\text { Street } \\
\text { pattern. }\end{array}$ & Jpeg data type. \\
\hline & $\begin{array}{l}\text { Landscape } \\
\text { value }\end{array}$ & $\begin{array}{l}\text { Size and } \\
\text { shape of the } \\
\text { building } \\
\text { blocks. }\end{array}$ & $\begin{array}{l}\text { Numeric data } \\
\text { type and 2D } \\
\text { cartography } \\
\text { (CAD or GIS). }\end{array}$ \\
\hline & & $\begin{array}{l}\text { Skyline and } \\
\text { height of the } \\
\text { city building } \\
\text { block. }\end{array}$ & $\begin{array}{l}\text { MDT and } \\
\text { rectified images } \\
\text { of the façades of } \\
\text { the city building } \\
\text { blocks. }\end{array}$ \\
\hline & & $\begin{array}{l}\text { Fifth façade } \\
\text { materiality. }\end{array}$ & $\begin{array}{l}\text { Georeferenced } \\
\text { rectified images } \\
\text { (Orthomosaics) }\end{array}$ \\
\hline
\end{tabular}

Table 1. Heritage values, valuable features and data types of the historic city of Cuenca.

\subsection{Selection of the documentation technique and heritage analysis}

In terms of the documentation techniques, different tools were used depending on the type of required data for the heritage analysis and future monitoring (Pavlidis, Koutsoudis, Arnaoutoglou, Tsioukas, \& Chamzas, 2007). Therefore, for the analysis of the historic value related to the roof's materiality, the digital aerial photogrammetry was used to manipulate images obtained by Remotely Piloted Aircraft Systems (RPAS). Then, orthomosaics were generated to allow the acquisition of an aerial representation of the historic landscape of the city. It enable the identification of different elements at the city building block scale such as roofs, backyards and orchards, as well as the recognition of indoor parking areas.

Another important aspect is the result of the images captured with RPAS in the Digital Surface Models (DSM), which shows the three-dimensional spatial distribution of the surface. The DSM was generated with photogrammetry techniques taking advantage of the overlap of the images and their stereoscopic potential. The aerial photographic survey was carried out using a RPAS Phantom 4 at an average flight height of 50 meters from the ground with frontal and lateral overlaps of $75 \%$ and $65 \%$, respectively. This resulted in 1738 images captured over a total area of 158.86 ha. From this survey, a better understanding of the urban-landscape structure was achieved. Additionally; evidence of a hidden but intense occupation within the city building block was revealed as part of important results for future decision-making. As it was explained before, the inner part of the city building blocks are not visible from street view, but they can also suffer alterations to the colonial architectural typologies, materials or land use. Thereby, the traditional orchards and backyards are transformed into tall buildings or extensive parking areas. Phenomena only recognizable through aerial surveys (figure 3 ). The DSM also facilitate recognizing with greater precision level the heights and visible materials in the orthomosaic, and even the roof slope.
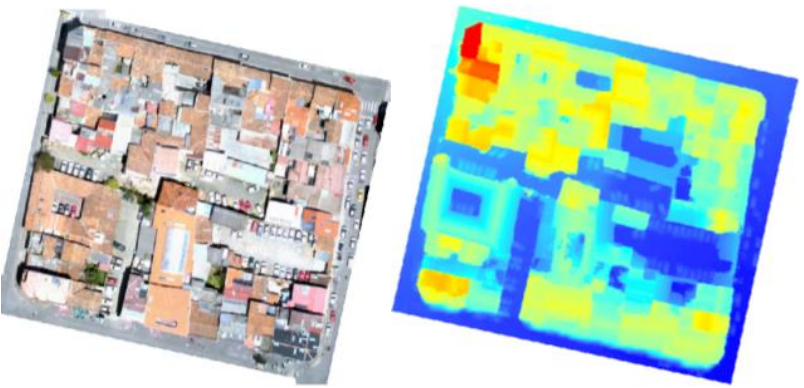

Figure 3. Detection of the parking spaces and interior buildings at the inner part of the city building blocks.

The information provided by the DSM is complemented by the rectified images, generated by terrestrial photogrammetry of the façades of the city building blocks. Both allow conforming the Skyline of the urban city and controlling the heights (figure 4).

A Nikon 3200 SLR camera was used to survey an area of the historic city of Cuenca corresponding to 16 city building blocks. Satisfactory results were obtained from 8 city building blocks; it means, that the façades representations do not have excessive deformations. The remaining surveyed façades suffered from smooth surfaces, making difficult the recognition of similar characteristics between photographs, essential requirement in the use of the (Structure from Motion) SfM algorithm, in charge of the photogrammetry process. For the photographic surveying 3 indispensable characteristics were imposed within the research: 1) to try to ensure that the captured building occupies most of the photographic frame, 2) the photo plane should be parallel to the facades (without inclinations that generate vanishing points) and 3) that between successive photographs the lateral overlap must be around $60 \%$. For each city building block there are approximately 50 photos.
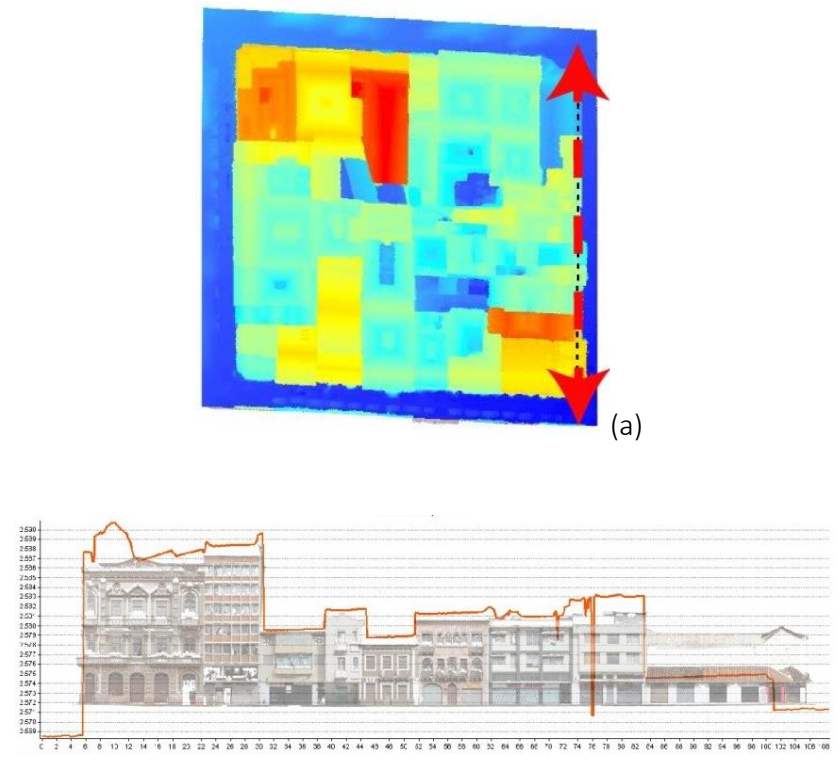

(b)

Figure 4. City building block skyline defined by terrestrial photogrammetry (a) and confirmed by the MDS (b).

As a complimented, the Terrestrial Laser Scan (TLS) was used for the identification of detailed elements at the facades and interior spaces. For some facades, the photogrammetry 
technique was implemented aiming to increase the accuracy level and to reduce the data processing time (Mañana-Borrazas, Rodríguez Paz, \& Blanco-Rotea, 2008). Nevertheless, as it is known a greater level of detail increases exponentially the amount of data generated. Thus, this research explore, use and analysed the heritage data efficiently and effective for urban heritage monitoring. For this purpose, image processing was used, through segmentation techniques and supervised classification of architectural elements at different scales (Huang \& Zhang, 2013). This strategy allows obtaining information on the materiality, location and general shapes of buildings and city buildings blocks important for the control of heritage values related to history and characteristics of the studied elements (See figure 5).

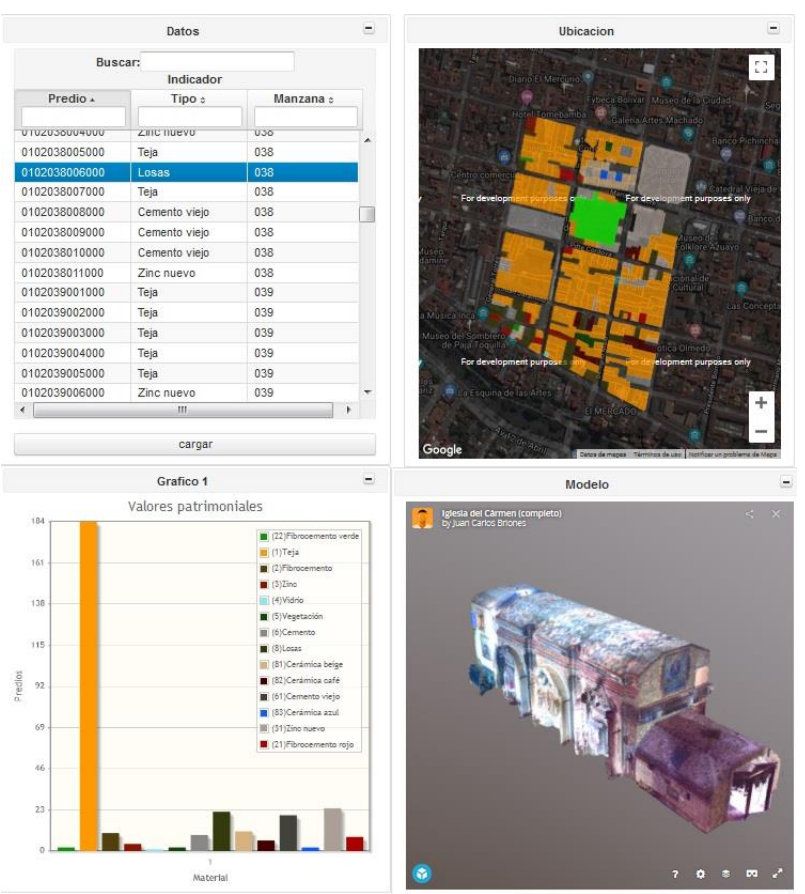

Figure 5. Multicriteria identification (proposed analysis): heights, areas of materiality, registration databases for the selected city building blocks, connected with the threedimensional information gathered of the same selected area.

\section{RESULTS}

The key finding from this research is that combination of different documentation techniques treated as clusters of particular data allow managing huge amounts of information. In addition, it gives the possibility to execute important heritage analysis at the city level, covering existing management requirements at this scale.

Thereby, the results has demonstrated that the heritage managing process for the historic city can be executed at a different scales and the outcomes are rapidly obtained; it means that the combination of these heritage documentation and segmentation techniques has allowed a significant reduce of processing time in relation to heritage data and the size of the study area. Currently other analysis are being included depending on the required management decision.

\section{CONCLUSIONS}

The WHS of Cuenca-Ecuador illustrates the capacities of relating heritage documentation tools and the existing heritage management requirements. It aims to change the ad-hoc management practices and overcome the existing gaps between data management and heritage conservation. Furthermore, the test of a heritage management process revealed that heritage data have direct implications on the type of analysis and therefore the decision-making that could be taken. It gives an answer to a specific conservation problem at the urban level, based on heritage values and the control that need through time.

Even if the research is ongoing, until this point it has proved that the most important input of this management process is the articulation between heritage analysis, existing data and documentation techniques. In this case, the model is built upon past heritage inventories and different tools are combined to support heritage conservation by providing informed recommendations, which could improve the monitoring of heritage values at the city building block scale. Thereby, the control and decision-making procedures could be more efficient and effective, leading to the reduction in the number of unplanned interventions in a heritage city. This research obtained information about the spatial location, size and proportion of historical buildings that will allow an evaluation of heritage elements over time. It had opened the door to a new conservation strategy that is not only related physical elements but from the use of digital tools can support different conservation approaches.

The next step of this research is to reach a level of detail 2 (LOD2) according to the CityGML standard, to structure a geo database, which contains semantic information of the buildings in the historic centre of Cuenca. In order to achieve this goal, the adaptation to the standard ontologies of the CityGML model are being working, it includes the study of parameters for estimating certain heritage values, at the building, city building block and urban level. Additionally, the preliminary obtained results interpreted as heritage attributes such as the city building blocks area, heights, materiality and land use can be combine with the different spatial relationships, historical settlements and economic development, giving the possibility to understand the city and its elements from a more dynamic perspective.

\section{REFERENCES}

Bolognesi, M., Furini, A., Russo, V., Pellegrinelli, A., \& Russo, P. (2015). Testing the low-cost rpas potential in 3D cultural heritage reconstruction. ISPRS - International Archives of the Photogrammetry, Remote Sensing and Spatial Information Sciences. XL-5/W4. 229-235. 10.5194/isprsarchives-XL-5-W4229-2015.

Briones, J., Heras, V., Abril, C., \& Sinchi, E. (2017). Supervised classification processes for the characterization of heritage elements, case study: Cuenca-Ecuador. ISPRS Annals of the Photogrammetry, Remote Sensing and Spatial Information Sciences, IV-2/W2, págs. 39-45. Ottawa, Canada. Obtenido de https://www.isprs-ann-photogramm-remote-sensspatial-inf-sci.net/IV-2-W2/39/2017/isprs-annals-IV-2-W2-392017.pdf

Caraballo, C. (2011). Patrimonio Cultural, un enfoque diverso y comprometido, UNESCO, México. 
Green, S. B. (2014). A comparative assessment of structure from motion methods for archaeological research. Journal of Archaeological Science, 173-181.

Heras, V., Barzallo, G., Abril, C., \& Briones, J. (2016). Heritage inventory as the base for a monitoring system in the world heritage city of Cuenca. Structural Analysis of Historical Constructions (SAHC) 2016, (págs. 181-184). Leuven, Belgium. doi:10.1201/9781315616995-27

Huang, X., \& Zhang, L. (2013). An SVM Ensemble Approach Combining Spectral, Structural, and Semantic Features for the Classification of High-Resolution Remotely Sensed Imagery. IEEE Transactions on Geoscience and Remote Sensing, 51(1), 257-272. doi:10.1109/TGRS.2012.2202912

Mañana-Borrazas, P., Rodríguez Paz, A., \& Blanco-Rotea, R. (2008). Una experiencia en la aplicación del Láser Escáner 3D a los procesos de documentación y análisis del Patrimonio Construido: su aplicación a Santa Eulalia de Bóveda (Lugo) y San Fiz de Solovio (Santiago de Compostela). Arqueología de la Arquitectura, 15-32. Obtenido de http://arqarqt.revistas.csic.es/index.php/arqarqt/article/view/87

Pavlidis, G., Koutsoudis, A., Arnaoutoglou, F., Tsioukas, V., \& Chamzas, C. (2007). Methods for 3D digitization of Cultural Heritage. Journal of Cultural Heritage, 93-98. Obtenido de https://www.sciencedirect.com/science/article/abs/pii/S1296207 $40600121 \mathrm{X}$

Secretaria Nacional de Planificación y Desarrollo SENPLADES. (2017). Código Orgánico de Organización Territorial, Autonomía y Descentralización - COOTAD. Quito, Ecuador.

United Nations Educational, Scientific and Cultural Organization - UNESCO. (1999). Historic Centre of Santa Ana de los Rìos de Cuenca. Recuperado el 26 de 02 de 2019, de World Heritage List: https://whc.unesco.org/en/list/863/

United Nations Educational, Scientific and Cultural Organization - UNESCO. (2008). Convention concerning the protection of the World Cultural and Natural Heritage. World Heritage 32 COM (pág. 101pg). Quebec City, Canada: UNESCO. Obtenido de http://whc.unesco.org/en/sessions/32COM

Van Balen, K. (2008). The Nara Grid: An Evaluation Scheme Based on the Nara Document on Authenticity. APT Bulletin, 39(2/3), 39-45. Obtenido de http://www.jstor.org/stable/25433951 